\title{
Battling COVID-19: using old weapons for a new enemy
}

\author{
Rohit Kumar ${ }^{1}$, Nitin Gupta ${ }^{2}$, Parul Kodan ${ }^{3}$, Ankit Mittal', Manish Soneja ${ }^{1 *}$ and Naveet Wig ${ }^{1}$
}

\begin{abstract}
Coronavirus disease-19 (COVID-19) has reached pandemic proportions. Most of the drugs that are being tried for the treatment have not been evaluated in any randomized controlled trials. The purpose of this review was to summarize the in-vitro and in-vivo efficacy of these drugs on Severe Acute Respiratory Syndrome (SARS-CoV-2) and related viruses (SARS and Middle East Respiratory Syndrome) and evaluate their potential for re-purposing them in the management of COVID-19.
\end{abstract}

Keywords: SARS-CoV-2, Hydroxychloroquine, Lopinavir/ritonavir, Remdisivir, Nitazoxanide, Tocilizumab

\section{Introduction}

Coronavirus disease 2019 (COVID-19), a disease caused by severe acute respiratory syndrome coronavirus 2 (SARS-CoV-2), was first reported from Wuhan, China in December 2019 and it has already claimed more than forty thousand lives [1]. Although supportive measures and stringent infection control measures remain as the cornerstone of management, there is no known effective antiviral for this disease. After the spike (S) protein of the virus interacts with angiotensin-converting enzyme (ACE) receptor of the host cell, the virus enters by membrane fusion or receptor-mediated endocytosis. This is followed by replication using RNA dependent RNA polymerase, translation, virus assembly and release (Fig. 1). Several existing drugs have been identified that are postulated to act on one of these critical steps (Fig. $1)$. While the efforts to develop new and effective drugs are ongoing; until there are more definitive answers, effective repurposing from the existing arsenal of antivirals are being used every day. There is a call to deal with this pandemic at a war footing. Every intervention, howsoever small, with a potential benefit are being explored

\footnotetext{
*Correspondence: manishsoneja@gmail.com

'Department of Medicine, All India Institute of Medical Sciences, New Delhi 110029, India

Full list of author information is available at the end of the article
}

every day. Although, Infectious disease society of America recommends the use of the repurposed drugs in the setting of clinical trials alone due to lack of evidence; data from related viruses (like SARS-CoV-1 and MERS), in-vitro studies and growing shreds of clinical evidence from this pandemic are being used to choose the drugs which can be repurposed [2]. The drugs have been discussed under the following headings: anti-parasitic drugs, protease inhibitors, polymerase inhibitors, fusion inhibitors, monoclonal antibodies and miscellaneous (Table 1 and Table 2).

\section{Anti-parasitic drugs \\ Chloroquine (CQ) and hydroxychloroquine (HCQ)}

Chloroquine (CQ) is a synthetic form of quinine (derived from the bark of cinchona tree) and is widely used as an anti-malarial since the last seventy years. Hydroxychloroquine (HCQ) has an extra hydroxyl group at the end of the side chain and is commonly used in the management of lupus and rheumatoid arthritis. Both these drugs have shown to have some anti-viral properties and may be useful in treating patients with COVID-19. Both CQ and HCQ interfere with the glycosylation of ACE-2 receptor, which is essential for the viral entry $[49,50]$. Both the drugs are a weak base, and they interfere with the acidification of lysosome. This interferes with the

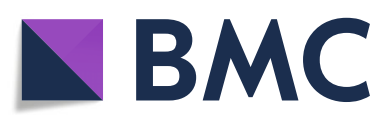

(C) The Author(s). 2020 Open Access This article is licensed under a Creative Commons Attribution 4.0 International License, which permits use, sharing, adaptation, distribution and reproduction in any medium or format, as long as you give appropriate credit to the original author(s) and the source, provide a link to the Creative Commons licence, and indicate if changes were made. The images or other third party material in this article are included in the article's Creative Commons licence, unless indicated otherwise in a credit line to the material. If material is not included in the article's Creative Commons licence and your intended use is not permitted by statutory regulation or exceeds the permitted use, you will need to obtain permission directly from the copyright holder. To view a copy of this licence, visit http://creativecommons.org/licenses/by/4.0/ The Creative Commons Public Domain Dedication waiver (http://creativecommons.org/publicdomain/zero/1.0/) applies to the data made available in this article, unless otherwise stated in a credit line to the data. 


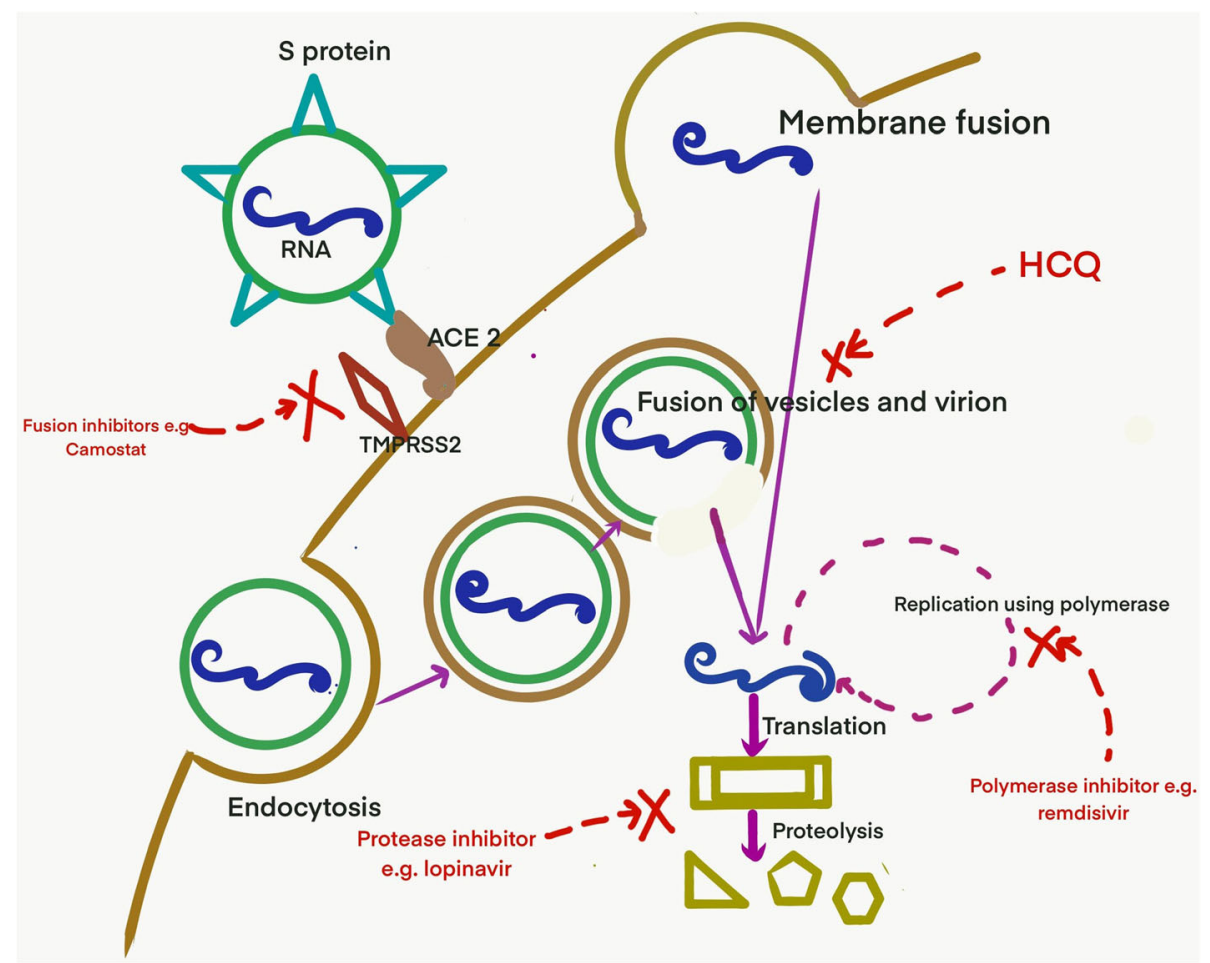

Fig. 1 Entry and replication of SARS-CoV-2 and the drugs that inhibit the various steps

$\mathrm{pH}$-dependent endosome mediated viral entry $[49,50]$. Both the drugs inhibit activation of cells by MAP kinase (P38 MAP kinase $[49,50]$ and inhibit post-translational modification of $\mathrm{M}$ proteins, thereby altering viral assembly and budding $[49,50]$. Also, both the drugs are immunomodulatory agents and reduce pro-inflammatory cytokines $[49,50]$. Compared to CQ, HCQ has a better in-vitro potency (7.6 times more potent), safety profile and lesser drug-drug interactions. HCQs have high accumulation in cells and long elimination half-life.

$C Q$ has shown activity against various viruses in-vitro including $\mathrm{HIV}$, hepatitis $\mathrm{A} / \mathrm{B} / \mathrm{C}$, influenza $\mathrm{A} / \mathrm{B}$, dengue, chikungunya, Nipah, Hendra, Lassa and Ebola [51-53]. In-vitro data also suggests that CQ can inhibit coronaviruses (SARS-CoV-1, MERS CoV and Human corona OC43) also [54-56]. Recent studies have shown that CQ is also active in-vitro against SARS-CoV-2 [57]. CQ and HCQ decreased viral replication of SARS-CoV-2 in a concentration dependant manner. HCQ exhibits superior in-vitro anti-viral effect in comparison to CQ when the drug is added before viral challenge [58]. In-vitro synergistic effect of HCQ and azithromycin has been demonstrated in a recent study [59].

CQ has some activity in mice against human coronavirus OC43 [60]. Both CQ and HCQ reach up to 700 times higher level in lungs than in plasma [50]. According to pharmacology based pharmacokinetic modelling by Yao et al., simulated lung, blood and plasma concentration of CQ increased slowly after the first dose was given and was yet to achieve steady-state on Day 10 . However, in HCQ, the concentration increased rapidly and reached a steady-state following the initial loading dose and subsequent maintenance dose [58].

Although in-vitro studies demonstrate the activity of CQ against SARS-CoV-2, this does not guarantee simultaneous in-vivo activity. For example, CQ was found to be effective in inhibiting replication of dengue, chikungunya and influenza in-vitro, but failed to show similar effects in in-vivo studies [60-62]. Preliminary reports from China in which 100 patients were given CQ showed early defervescence of fever and improvement in radiological findings. No serious adverse events were noted [63]. A French clinical trial of 36 PCR confirmed patients showed that virological clearance on Day 6 was significantly higher in $\mathrm{HCQ}$ arm compared to the control group (Table 1) [3]. In another study of 62 patients (31- standard treatment, 31- additional HCQ) with pneumonia associated with COVID-19 from China, additional HCQ for 5 days resulted in earlier remission of fever and cough [64]. Patients with severe/ critical illness were, however, excluded from the study. In a multicentric open labelled randomized controlled trial of 150 patients from China, there was no difference in virological conversion rate or improvement in clinical symptoms at day 10. However, the HCQ arm showed a better clinical response in posthoc analysis when the effect of 
Kumar et al. Tropical Diseases, Travel Medicine and Vaccines

(2020) 6:6

Page 3 of 10

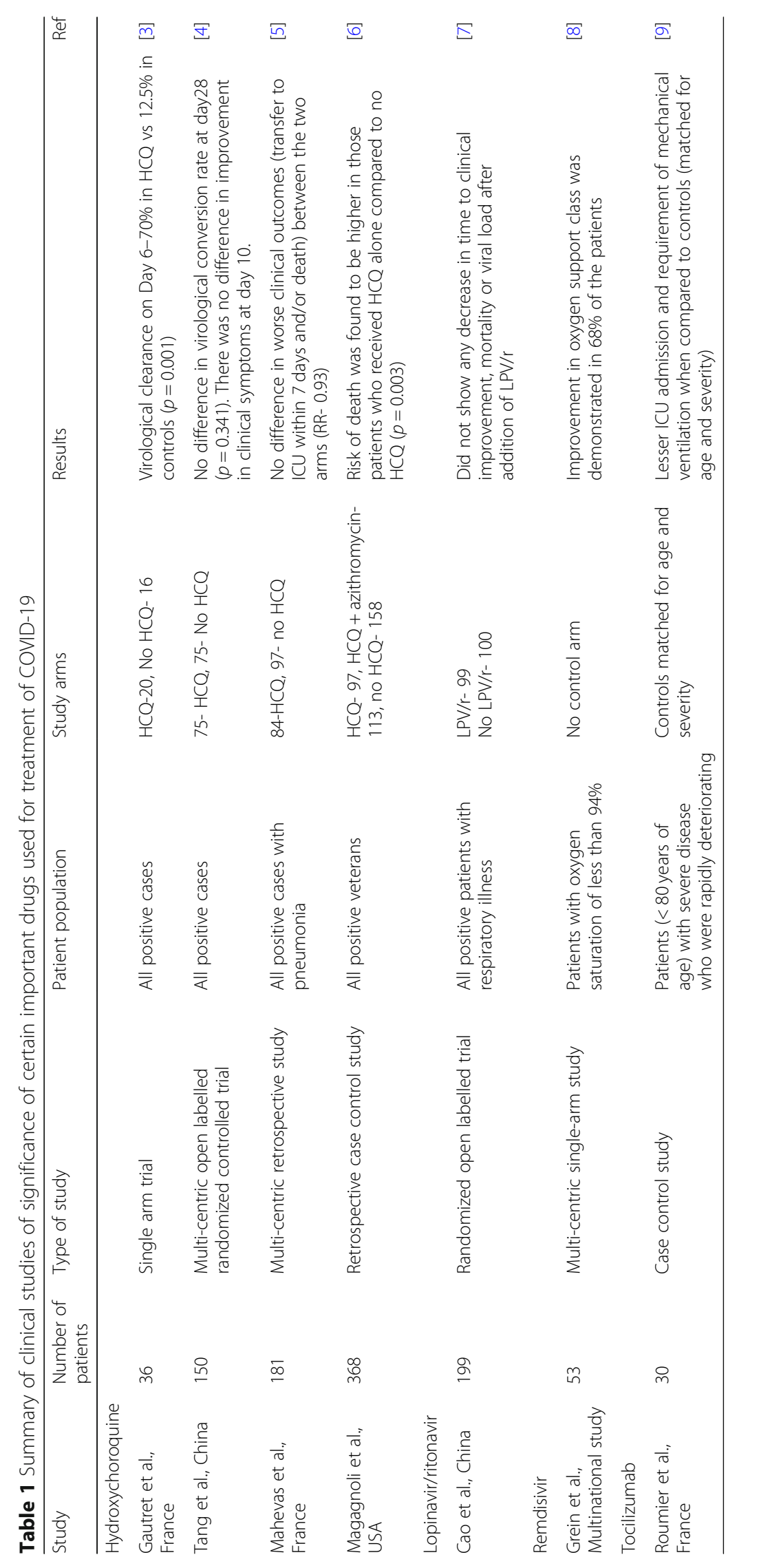




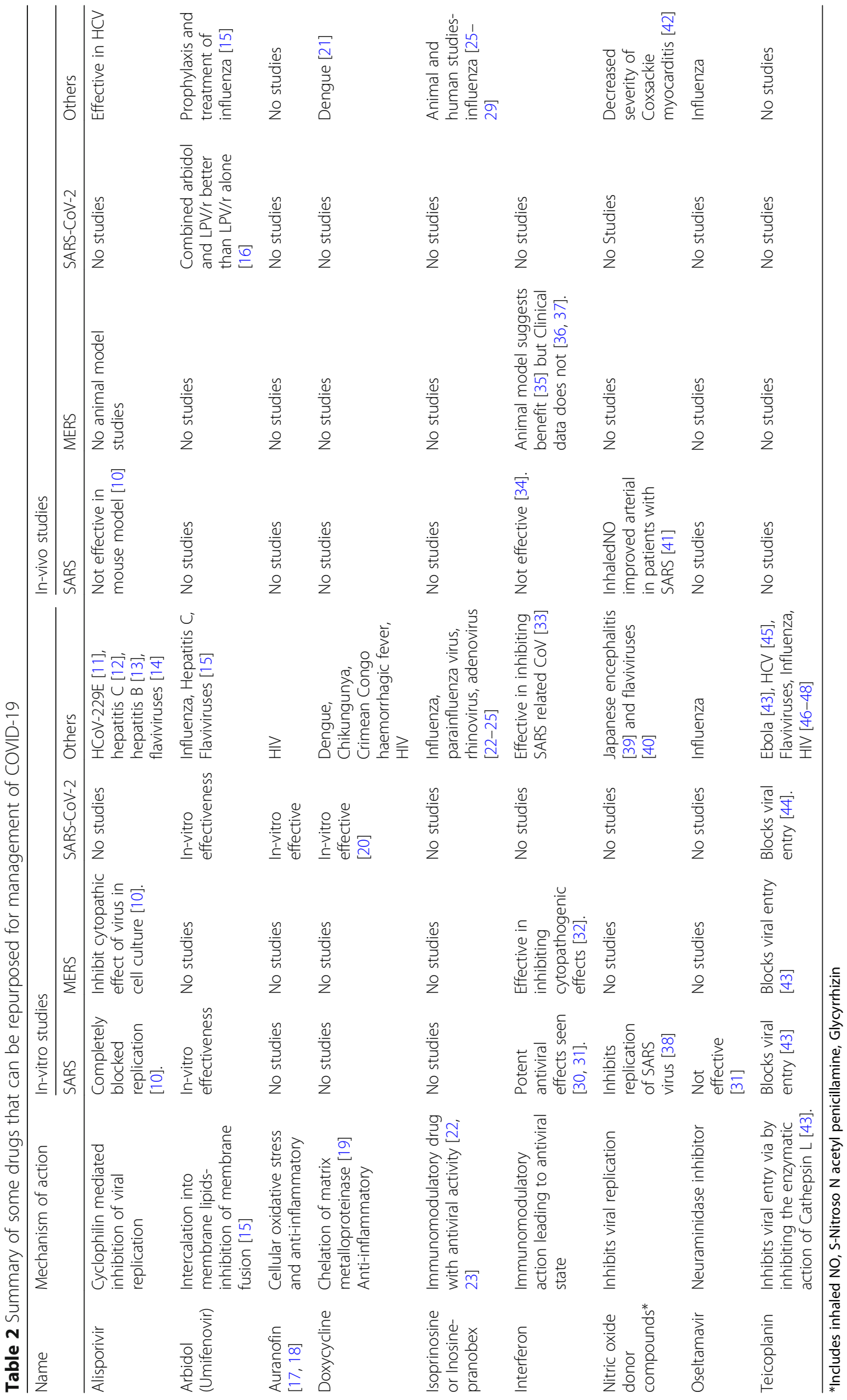


other anti-antivirals was removed (Table 1) [4]. A small French study of 11 patients by Molina et al. failed to show beneficial effects (early clearance of virus) of combining HCQ and azithromycin in patients with COVID19 [65]. In another multi-centric retrospective study of 181 patients with COVID pneumonia from France, there was no difference in worse clinical outcomes between the two arms (Table 1) [5]. In a quasi-randomized controlled trial by Barbosa et al., of the 63 recruited patients, 32 received HCQ while 31 received standard support. Higher respiratory support requirement was noted in the HCQ group after 5 days of therapy [66]. In a retrospective study on 368 veterans from the United States of America, risk of death was found to be higher in those patients who received HCQ alone compared to no HCQ. No difference in requirement of ventilation was found between HCQ and no HCQ group (Table 1) [6].

The dosing recommendation, according to modelling by Yao et al. recommends- Day 1-400 mg twice daily and day 2-5- $200 \mathrm{mg}$ twice daily [58]. However, the French group used a dosing regimen of $200 \mathrm{mg}$ thrice daily for 10 days [3]. Drug-drug interactions and comorbidities (pregnancy, chronic renal impairment) should be considered while defining the doses. Administration with food may be helpful as the bioavailability is increased with food. Although some experts are recommending routine use of $\mathrm{CQ}$ and $\mathrm{HCQ}$ as prophylaxis, there is no evidencing supporting this recommendation. $\mathrm{CQ}$ and HCQs have been successfully used for malarial prophylaxis, but similar results have not been observed for viral infections [61]. CQ has a narrow therapeutic window, but when appropriate dosing is used, it is relatively well tolerated. Compared to CQ, HCQs are better tolerated. Minor side effects include diarrhoea, nausea, vomiting and pruritus. Toxic doses may lead to lifethreatening cardiomyopathy, macular retinopathy and neurotoxicity.

\section{Nitazoxanide}

Nitazoxanide is an oral anti-parasitic drug that is active against several protozoans, cestodes, helminths. It exerts its anti-parasitic activity by inhibiting pyruvateferredoxin oxidoreductase (PFOR), an essential enzyme in anaerobic energy metabolism [67]. Recently, laboratory studies have suggested its role as a broad-spectrum antiviral agent [68]. In influenza, it inhibits the maturation of the viral hemagglutinin, whereas it interferes with viral morphogenesis in rotavirus [68]. It can also limit virus entry, viral release and cell-to-cell transmission. It can also interfere with host-regulated pathways and can inhibit/ suppress the production of proinflammatory cytokines, including IL-6 and TNF alpha $[69,70]$.
Nitazoxanide has been shown to inhibit SARS-CoV-2 in in-vitro studies $[57,71]$. In an in-vivo study based on a mouse model, nitazoxanide was found to markedly lower plasma IL-6 levels [70]. In a clinical trial conducted by Gamino-Arroyo et al., nitazoxanide did not show any difference when compared to placebo in patients with influenza [72]. The same trial included 17 cases of coronavirus and did not show any effect of nitazoxanide on the outcome.

Although in-vitro studies indicate that there might be a potential role of nitazoxanide in management of COVID-19, there is no clear evidence that it might be useful in the clinical setting. It is generally welltolerated, and side effects include gastrointestinal disturbances, transaminitis, elevated creatinine and enlarged salivary glands [67].

\section{Niclosamide}

Niclosamide is a chlorinated salicylamide used for the treatment of infection with trematodes [73]. It inhibits ATP production by uncoupling oxidative phosphorylation in the mitochondria of the parasite [74]. It is also known to have antiviral effects by blocking the endosomal acidification [73, 75]. Endosomal acidification is important for the fusion of the viral envelope protein with the host membrane [76-78].

Niclosamide inhibits replication of various viruses invitro including influenza, dengue, chikungunya virus, Ebola virus and Hepatitis C [75-77]. It also inhibits replication of SARS and MERS viruses [79, 80]. Niclosamide has not been evaluated yet for the treatment of viral infections (coronavirus) in animal models or clinical studies.

Niclosamide has potential activity against coronaviruses based on in vitro studies alone, but there is a lack of data for the efficacy of this drug on SARS-CoV-2. Use of niclosamide is associated with mild and infrequent side effects that include gastrointestinal disturbances, malaise, pruritus and lightheadedness.

\section{Ivermectin}

Ivermectin is a broad-spectrum anti-parasitic drug used commonly in the treatment of strongyloidiasis and onchocerciasis [81]. It acts by inhibiting nuclear transport activity. The in-vitro activity has been demonstrated against several viruses including HIV, dengue, West Nile virus and influenza. Recently, it has also been found to inhibit SARS-CoV-2 in cell cultures [82]. In-vivo studies for the use of ivermectin as an antiviral are scarce. In a clinical trial for the use of ivermectin in dengue, it reduced levels of NS1 antigen but had no impact on viral load and clinical outcomes [83]. It is a relatively safe drug with good tolerability [81]. 


\section{Protease inhibitors \\ Lopinavir/ritonavir (LPV/r)}

Lopinavir is a protease inhibitor used commonly for the treatment of HIV 1 infection. Ritonavir is used for boosting the lopinavir levels as a combination in subtherapeutic doses for its inhibitory action on CYP3A4. In HIV, LPV inhibits the protease enzyme (aspartic protease family), thereby preventing the cleavage of Gag-Pol protein precursors. This results in the formation of immature and non-infectious virions. It is postulated that LPV has similar action on SARS-CoV-1 by inhibiting the chymotrypsin-like protease.

$\mathrm{LPV} / \mathrm{r}$ has in-vitro activity against SARS-CoV-1 and MERS CoV [32, 84]. In another study, the addition of $\mathrm{LPV} / \mathrm{r}$ to IFN B in MERS CoV infected cell lines did not enhance the activity of IFN B alone [85]. LPV/r was also found to have activity against Human coronavirus $229 \mathrm{E}$ [32]. No in-vitro data on SARS-CoV-2 has been reported as of now. In humanized transgenic mice, LPV/r plus IFN $\mathrm{B}$ was not able to reduce the viral load of MERS CoV [85]. However, in non-human primate models (marmosets) infected with MERS CoV, LPV/r was able to reduce viral load and improve clinical progress [86]. In a study on health care workers exposed to MERS, lower rates of infection were noticed when they were given post-exposure prophylaxis of ribavirin and lopinavir/ritonavir for 14 days [87]. In patients of SARS-CoV-1 without ARDS, the addition of LPV/r to ribavirin and corticosteroids resulted in better clinical outcomes when compared to historical controls who received ribavirin and corticosteroids [84]. In a retrospective matched cohort study, LPV/r resulted in better clinical outcomes in patient with SARS [88]. Small case series have reported apparent benefit with $\mathrm{LPV} / \mathrm{r}$. Ten patients with COVID-19 were given sustained LPV/r with good outcomes [16]. In another study, 17 patients who received oral $\mathrm{LPV} / \mathrm{r}$ alone, $52.9 \%$ of the patients showed clearance of viraemia on day 14 [16]. However, an open labelled trial of 199 COVID-19 patients did not show any decrease in time to clinical improvement, mortality or viral load after addition of LPV/r (Table 1) [7]. Although this trial failed to show any benefit of LPV/r, it can be argued that patients had already developed lung injury at the time of enrolment. The median time of enrolment in this study was 13 days [7]. It is postulated that since the viraemia is present in the early part of the illness and the lung involvement is a result of cytokine release and immune response, the drug may be effective when given in the early part of the illness. In the study by Chan et al. on patients with SARS-CoV-1, LPV/r was beneficial when given in the early part of illness but did not have any significant impact when it was given as a salvage or rescue [88].

A dose of 400/100 twice daily for up to 14 days has been tried in most studies. It has to be kept in mind that this drug has several drug-drug interactions and may require dose modification in pregnancy. No dose modification is required in patients with kidney disease or mild hepatic impairment. It is recommended to avoid LPV/r in patients with severe hepatic impairment (Child-Pugh $\mathrm{C}$ or Alanine transaminase $>5 \mathrm{X}$ Upper limit of normal). Gastrointestinal side effects and hypertriglyceridemia are common in patients on LPV/r. Peripheral lipoatrophy and visceral adiposity are also noticed in patients on long-term LPV/r. Serious adverse events include pancreatitis, hepatotoxicity and QT prolongation.

\section{Simeprevir and Paritaprevir}

Simeprevir and paritaprevir are oral NS3/4A protease (chymotrypsin-like protease) inhibitors that are used for the treatment of chronic hepatitis C [89]. Chymotrypsin like protease is also present in SARS CoV-2, which is essential to cleave an $800-\mathrm{kDa}$ polypeptide to generate various proteins [90]. There are no in-vitro or in-vivo studies available that have assessed the role of these drugs in coronavirus infections. However, molecular docking analysis studies indicate simeprevir and paritaprevir could fit well to the binding pocket of protease $[90,91]$. The safety profile of both drugs is generally acceptable. Use of simeprevir is associated with hyperbilirubinemia [89].

\section{Polymerase inhibitor \\ Remdesivir}

Remdesivir is an adenosine analogue that binds to RNAdependent RNA polymerase. It gets incorporated into nascent viral RNA chains resulting in its premature termination.

Replication inhibition has been demonstrated in a wide range of viruses in vitro and in vivo [57, 85, 92-97]. The therapeutic efficacy of remdesivir was first described in an animal model against Ebola. Subsequently, Dyer et al. described preliminary findings suggesting mortality benefit when remdesivir was given in the early stages of Ebola [94]. The drug has exhibited in vitro and in-vivo activity against SARS-CoV-1 and MERS-CoV [85, 92, 96]. Wang et al. showed that the use of remdesivir is effective against SARS-CoV-2 in Vero E6 cell lines [57]. Case reports of success with remdesivir in patients with COVID-19 have been documented $[98,99]$. In a recent multi-centric single-arm study by Grein et al., remdesivir was used in 53 patients of COVID-19, improvement in oxygen support class was demonstrated in $68 \%$ of the patients (Table 1) [8]. This drug has a long half-life and needs once-daily dosage. The trial by Grein et al. used dosing of $200 \mathrm{mg}$ on day one, followed by $100 \mathrm{mg}$ from day 2 to day 10 [8]. The most common side effects are transient gastrointestinal symptoms and transaminitis. 


\section{Favipiravir}

Favipiravir is a promising antiviral drug which targets the viral RNA-dependent RNA polymerase [100]. The drug gets converted to its active form by host enzymes and has exhibited considerable activity in influenza [100]. In a small clinical trial of COVID-19 patients, when compared to another potential drug arbidol, it showed a faster clinical recovery rate at day seven and more effectively reduced incidence of fever and cough [101]. In an open labelled trial of 70 patients in China, favipiravir had better viral clearance and improved lung imaging when compared to lopinavir/ritonavir [102]. The dosing used in the study was $1600 \mathrm{mg}$ twice daily on the first day and $600 \mathrm{mg}$ twice daily on day 2 to day 14 . Side effects include raised serum uric acid levels, psychiatric symptoms and gastrointestinal disturbances [101].

\section{Nucleoside analogues}

Sofosbuvir is an oral nucleoside analogue (NS5B polymerase inhibitor) that is used for the treatment of Hepatitis C [103]. Invitro studies have shown its effectiveness in SARS CoV 1. Molecular docking studies have shown that sofosbuvir may be active against COVID-19 [103].

Galidesivir is another broad-spectrum antiviral drug that has exhibited efficacy against Ebola and yellow fever [104].

Ribavirin is used for the treatment of hepatitis $C$ and viral hemorrhagic fevers. The in-vivo studies in SARSCoV-1 and in-vitro studies in SARS-CoV-2 have not been encouraging. Besides, usual clinical dosing is associated with haematological toxicity.

\section{Fusion inhibitors}

Nafamostat mesylate and Camostat mesylate are drugs which are used to treat acute pancreatitis. These drugs act by effectively blocking the membrane fusion between the viral envelope and host cell plasma membrane. The in-vitro activity has been demonstrated for MERS-CoV [105]. Similarly, enfuvirtide and SC29EK are fusion inhibitors used for the treatment of HIV [106, 107]. These drugs have been suggested to have a possible role in SARS-CoV-2.

\section{Monoclonal antibodies \\ Tocilizumab}

Tocilizumab is a humanized monoclonal antibody that is used in several rheumatological conditions like rheumatoid arthritis, juvenile idiopathic arthritis, Castleman's disease, giant cell arteritis and cytokine release syndrome caused by CAR-T treatment [108]. Tocilizumab acts against the soluble and membranebound IL-6 receptors and inhibits the inflammatory action of IL-6 [108]. Pulmonary injury and ARDS has been postulated to be a result of hyper-inflammatory state in the latter half of the illness in COVID-19 due to increase in levels of pro-inflammatory cytokines such as IL-6 [109, 110]. Similar studies from patients with influenza have shown that high IL-6 levels are associated with severity [111]. However, mice models show that IL-6 is also useful to prevent virus-induced neutrophil death and is a useful host response in early infection. Therefore, it is imperative to understand that molecules such as tocilizumab can only be used only in patients with severe disease when cytokine release syndrome is suspected as evidenced by an increased IL-6. There are no published reports of the use of tocilizumab in SARS and MERS. Preliminary case series have shown good outcomes with tocilizumab $(400 \mathrm{mg})$ in 21 patients with severe or critical COVID-19. All the patients either improved (19/21) or were improving $(2 / 21)$ at the time of reporting [112]. In another study of 30 patients, it was found that the use of tocilizumab was associated with lesser ICU admission and requirement of mechanical ventilation when compared to controls (Table 1) [9].

Tocilizumab is given as an intravenous infusion over 1 hour at a dose of $8 \mathrm{mg} / \mathrm{kg}$ in patients who weigh more than $30 \mathrm{~kg}$ (maximum dose- $800 \mathrm{mg}$ ). This can be repeated for three additional times, 8 hours apart. Adverse reactions include upper respiratory tract infections, headache and transaminitis [108]. In COVID-19 clinical studies, tocilizumab was shown to be safe except for a few reports of transaminitis [9].

\section{Siltuximab}

Siltuximab is another chimeric antibody that blocks the effect of IL-6 and is used for the treatment of multicentric Castleman's disease. In a single-arm trial of 21 patients with COVID and ARDS from Italy, 33\% of the patients improved, and $43 \%$ of the patients remained stable on treatment [113].

\section{Meplazumab}

The spike protein of SARS-CoV-2 binds to CD 147 of the host cell during entry. Meplazumab is a humanized monoclonal antibody that acts against CD147 and therefore has a potential role in the management of COVID19. In a small open labelled trial from China $(n=28)$, use of intravenous meplazumab $(n=17)$ was associated with better virological (time to negativity) and clinical outcomes (lesser severity and earlier discharge) when compared to controls $(n=11)$ [114]. No adverse effects were reported with meplazumab.

\section{Miscellaneous drugs}

Several other drugs with anti-viral properties are being re-purposed for use in COVID-19. The details of the following drugs have been tabulated in Table 2: alisporivir, 
arbidol, auranofin, doxycycline, isprinosine, interferon, nitric oxide compounds, oseltamivir and teicoplanin.

\section{Conclusion}

The data on these drugs are increasing every day. It is tempting to try these drugs in the name of safety or ease of availability. Some initial studies showed benefit with HCQ in early viral clearance. Subsequent studies failed to show such benefit. Lopinavir/ritonavir was shown to be ineffective when started late in patients with COVID pneumonia. However, their effectiveness in early COVID is debatable. Initial results of compassionate use of remdesivir are encouraging but the drug needs to be evaluated in well-designed randomized trials before it can be used routinely. Tocilizumab has been proposed for use in severe or life-threatening cases of cytokine release syndrome based on studies with very small sample size which have shown good results. Till the time, the data on these drugs come from well conducted clinical trials are available, judicious and well-informed use is the need of the hour.

\section{Acknowledgements}

None.

\section{Authors' contributions}

RK, MS and NW conceived the idea. RK, NG, PK and AM were involved in literature review. RK, NG, PK and AM were involved in making th efirst draft of the manuscript. NG, MS and NW were involved in editimg of the manuscript. NG was involved in making the figure. NG, RG and AK were involved in making the tables. MS is the overall guarantor of the manuscript. The authors read and approved the final manuscript.

\section{Funding}

None.

\section{Availability of data and materials}

Not applicable.

\section{Ethics approval and consent to participate}

Not applicable.

\section{Consent for publication}

Not applicable.

\section{Competing interests}

None.

\section{Author details}

${ }^{1}$ Department of Medicine, All India Institute of Medical Sciences, New Delhi 110029, India. ${ }^{2}$ Department of Infectious Diseases, Kasturba Medical College, Manipal, Karnataka 576104, India. ${ }^{3}$ Dr Ram Manohar Lohia hospital \& Post-Graduate Institute of Medica education and Research, New Delhi 110001, India.

Received: 9 April 2020 Accepted: 8 May 2020

Published online: 20 May 2020

\section{References}

1. Zhang X. Epidemiology of Covid-19. N Engl J Med. 2020;27:382.

2. Bhimraj A, Morgan RL, Shumaker AH, Lavergne V, Baden L, Cheng VC, Edwards KM, Gandhi R, Muller WJ, O'Horo JC, Shoham S. Infectious diseases Society of America guidelines on the treatment and management of patients with COVID-19. Clin Infect Dis. 2020.
3. Gautret $P$, Lagier J-C, Parola P, Hoang VT, Meddeb L, Mailhe M, et al Hydroxychloroquine and azithromycin as a treatment of COVID-19: results of an open-label non-randomized clinical trial. Int J Antimicrob Agents. 2020;105949.

4. $\quad$ Tang W, Cao Z, Han M, Wang Z, Chen J, Sun W, et al. Hydroxychloroquine in patients with COVID-19: an open-label, randomized, controlled trial. medRxiv. 2020;2020.04.10.20060558.

5. Mahevas M, Tran V-T, Roumier M, Chabrol A, Paule R, Guillaud C, et al. No evidence of clinical efficacy of hydroxychloroquine in patients hospitalized for COVID-19 infection with oxygen requirement: results of a study using routinely collected data to emulate a target trial. medRxiv. 2020;2020.04.10. 20060699.

6. Magagnoli J, Narendran S, Pereira F, Cummings T, Hardin JW, Sutton SS, et al. Outcomes of hydroxychloroquine usage in United States veterans hospitalized with Covid-19. medRxiv. https://doi.org/10.1101/2020.04.16. 20065920

7. Cao B, Wang Y, Wen D, Liu W, Wang J, Fan G, et al. A trial of Lopinavirritonavir in adults hospitalized with severe Covid-19. N Engl J Med. 2020; 382(19):1787-99.

8. Grein J, Ohmagari N, Shin D, Diaz G, Asperges E, Castagna A, et al. Compassionate use of Remdesivir for patients with severe Covid-19. N Engl J Med. 2020;0(0):null.

9. Roumier M, Paule R, Groh M, Vallee A, Ackermann F. Interleukin-6 blockade for severe COVID-19. medRxiv. 2020;2020.04.20.20061861.

10. de Wilde AH, Falzarano D, Zevenhoven-Dobbe JC, Beugeling C, Fett C, Martellaro C, et al. Alisporivir inhibits MERS- and SARS-coronavirus replication in cell culture, but not SARS-coronavirus infection in a mouse model. Virus Res. 2017;228:7-13.

11. de Wilde AH, Zevenhoven-Dobbe JC, van der Meer $Y$, Thiel V, Narayanan $K$, Makino S, et al. Cyclosporin a inhibits the replication of diverse coronaviruses. J Gen Virol. 2011;92(Pt 11):2542-8.

12. Watashi K, Ishii N, Hijikata M, Inoue D, Murata T, Miyanari Y, et al. Cyclophilin $B$ is a functional regulator of hepatitis C virus RNA polymerase. Mol Cell. 2005;19(1):111-22

13. Phillips S, Chokshi S, Chatterji U, Riva A, Bobardt M, Williams R, et al. Alisporivir inhibition of hepatocyte cyclophilins reduces HBV replication and hepatitis B surface antigen production. Gastroenterology. 2015;148(2):403414.e7.

14. Qing M, Yang F, Zhang B, Zou G, Robida JM, Yuan Z, et al. Cyclosporine inhibits Flavivirus replication through blocking the interaction between host Cyclophilins and viral NS5 protein. Antimicrob Agents Chemother. 2009; 53(8):3226-35.

15. Haviernik J, Štefánik M, Fojtíková M, Kali S, Tordo N, Rudolf I, et al. Arbidol (Umifenovir): a broad-spectrum antiviral drug that inhibits medically important arthropod-borne flaviviruses. Viruses. 2018;10(4):184.

16. Deng L, Li C, Zeng Q, Liu X, Li X, Zhang H, Hong Z, Xia J. Arbidol combined with LPV/r versus LPV/r alone against Corona Virus Disease 2019: A retrospective cohort study. J Infect. 2020.

17. Roder C, Thomson MJ. Auranofin: repurposing an old drug for a Golden new age. Drugs R D. 2015;15(1):13-20.

18. Rothan H, Stone S, Natekar J, Kumari P, Arora K, Kumar M. The FDAapproved gold drug Auranofin inhibits novel coronavirus (SARS-COV-2) replication and attenuates inflammation in human cells. bioRxiv. 2020.

19. Sodhi M, Etminan M. Therapeutic Potential for Tetracyclines in the Treatment of COVID-19. Pharmacotherapy. 2020. https://doi.org/10.1002/ phar.2395 [Epub ahead of print].

20. In vitro antiviral activity of doxycycline against SARS-CoV-2 - IHU. [cited 2020 Apr 23]. Available from: https://www.mediterranee-infection.com/invitro-antiviral-activity-of-doxycycline-against-sars-cov-2/.

21. Fredeking TM, Zavala-Castro JE, González-Martínez P, Moguel-Rodríguez W, Sanchez EC, Foster MJ, et al. Dengue patients treated with doxycycline showed lower mortality associated to a reduction in IL-6 and TNF levels. Recent Pat Antiinfect Drug Discov. 2015;10(1):51-8.

22. Campoli-Richards DM, Sorkin EM, Heel RC. Inosine pranobex. Drugs. 1986; 32(5):383-424.

23. Sliva J, Pantzartzi CN, Votava M. Inosine pranobex: a key player in the game against a wide range of viral infections and non-infectious diseases. Adv Ther. 2019;36(8):1878-905.

24. Campo M, Chiavaro I, Petralia S, Bernardini A. In vitro lymphocyte sensitivity test to methisoprinol in different pathological conditions. Immunopharmacol. 1982;4(1-2):109-26. 
25. Muldoon RL, Mezny L, Jackson GG. Effect of isoprinosine against influenza and some other viruses causing respiratory diseases. Antimicrob Agents Chemother. 1972;2(3):224-8.

26. Pavlova EL, Simeonova LS, Gegova GA. Combined efficacy of oseltamivir, isoprinosine and ellagic acid in influenza a (H3N2)-infected mice. Biomed Pharmacother. 2018;98:29-35.

27. Longley S, Dunning RL, Waldman $\mathrm{RH}$. Effect of isoprinosine against challenge with a (H3N2)/Hong Kong influenza virus in volunteers. Antimicrob Agents Chemother. 1973;3(4):506-9.

28. Litzman J, Lokaj J, Krejčí M, Pešák S, Morgan G. Isoprinosine does not protect against frequent respiratory tract infections in childhood. Eur $\mathrm{J}$ Pediatr. 1999;158(1):32-7.

29. Beran J, Šalapová E, Špajdel M. Inosine pranobex is safe and effective for the treatment of subjects with confirmed acute respiratory viral infections: analysis and subgroup analysis from a phase 4, randomised, placebocontrolled, double-blind study. BMC Infect Dis. 2016;16(1):648

30. Cinatl J, Morgenstern B, Bauer G, Chandra P, Rabenau H, Doerr HW. Treatment of SARS with human interferons. Lancet. 2003;362(9380):293-4.

31. Tan ELC, Ooi EE, Lin C-Y, Tan HC, Ling AE, Lim B, et al. Inhibition of SARS coronavirus infection in vitro with clinically approved antiviral drugs. Emerg Infect Dis. 2004;10(4):581-6

32. de Wilde AH, Raj VS, Oudshoorn D, Bestebroer TM, van Nieuwkoop S, Limpens RWAL, et al. MERS-coronavirus replication induces severe in vitro cytopathology and is strongly inhibited by cyclosporin a or interferon-a treatment. J Gen Virol. 2013;94(8):1749-60.

33. He R, Adonov A, Traykova-Adonova M, Cao J, Cutts T, Grudesky E, et al. Potent and selective inhibition of SARS coronavirus replication by aurintricarboxylic acid. Biochem Biophys Res Commun. 2004;320(4):1199-203.

34. Stockman LJ, Bellamy R, Garner P. SARS: systematic review of treatment effects. PLoS Med. 2006;3(9):e343.

35. Falzarano D, De Wit E, Rasmussen AL, Feldmann F, Okumura A, Scott DP, et al. Treatment with interferon- $a 2 b$ and ribavirin improves outcome in MERSCoV-infected rhesus macaques. Nat Med. 2013;19(10):1313-7.

36. Morra ME, Van Thanh L, Kamel MG, Ghazy AA, Altibi AMA, Dat LM, et al. Clinical outcomes of current medical approaches for Middle East respiratory syndrome: a systematic review and meta-analysis. Rev Med Virol. 2018;28(3):e1977.

37. Al-Tawfiq JA, Momattin H, Dib J, Memish ZA. Ribavirin and interferon therapy in patients infected with the Middle East respiratory syndrome coronavirus: an observational study. Int J Infect Dis. 2014;20:42-6.

38. Keyaerts E, Vijgen L, Chen L, Maes P, Hedenstierna G, Van Ranst M. Inhibition of SARS-coronavirus infection in vitro by S-nitroso-Nacetylpenicillamine, a nitric oxide donor compound. Int J Infect Dis. 2004; 8(4):223-6.

39. Lin YL, Huang YL, Ma SH, Yeh CT, Chiou SY, Chen LK, et al. Inhibition of Japanese encephalitis virus infection by nitric oxide: antiviral effect of nitric oxide on RNA virus replication. J Virol. 1997;71(7):5227-35.

40. Crance JM, Scaramozzino N, Jouan A, Garin D. Interferon, ribavirin, 6azauridine and glycyrrhizin: antiviral compounds active against pathogenic flaviviruses. Antivir Res. 2003;58(1):73-9.

41. Chen L, Liu P, Gao H, Sun B, Chao D, Wang F, et al. Inhalation of nitric oxide in the treatment of severe acute respiratory syndrome: a rescue trial in Beijing. Clin Infect Dis. 2004;39(10):1531-5.

42. Zhang $\mathrm{H}$, Song $\mathrm{Y}$, Zhang Z. Glycyrrhizin administration ameliorates coxsackievirus B3-induced myocarditis in mice. Am J Med Sci. 2012;344(3): 206-10.

43. Zhou N, Pan T, Zhang J, Li Q, Zhang X, Bai C, et al. Glycopeptide antibiotics potently inhibit Cathepsin $\mathrm{L}$ in the late endosome/lysosome and block the entry of Ebola virus, Middle East respiratory syndrome coronavirus (MERSCoV), and severe acute respiratory syndrome coronavirus (SARS-CoV). J Biol Chem. 2016;291(17):9218-32.

44. Zhang J, Ma X, Yu F, Liu J, Zou F, Pan T, et al. Teicoplanin potently blocks the cell entry of 2019-nCoV. bioRxiv. 2020

45. Maieron A, Kerschner H. Teicoplanin therapy leading to a significant decrease in viral load in a patient with chronic hepatitis C. J Antimicrob Chemother. 2012;67(10):2537-8

46. Bereczki I, Kicsák M, Dobray L, Borbás A, Batta G, Kéki S, et al. Semisynthetic teicoplanin derivatives as new influenza virus binding inhibitors: synthesis and antiviral studies. Bioorg Med Chem Lett. 2014;24(15):3251-4.

47. De Burghgraeve T, Kaptein SJ, Ayala-Nunez NV, Mondotte JA, Pastorino B, Printsevskaya SS, et al. An analogue of the antibiotic teicoplanin prevents flavivirus entry in vitro. PLoS One. 2012;7(5):e37244.
48. Preobrazhenskaya MN, Olsufyeva EN. Polycyclic peptide and glycopeptide antibiotics and their derivatives as inhibitors of HIV entry. Antivir Res. 2006; 71(2-3):227-36

49. Devaux CA, Rolain JM, Colson P, Raoult D. New insights on the antiviral effects of chloroquine against coronavirus: what to expect for COVID-19? Int J Antimicrob Agents. 2020;12:105938.

50. Liu J, Cao R, Xu M, Wang X, Zhang H, Hu H, et al. Hydroxychloroquine, a less toxic derivative of chloroquine, is effective in inhibiting SARS-COV-2 infection in vitro. Cell Discovery. 2020;6(1):1-4.

51. Inglot AD. Comparison of the antiviral activity in vitro of some non-steroidal anti-inflammatory drugs. J Gen Virol. 1969;4(2):203-14.

52. Miller DK, Lenard J. Antihistaminics, local anesthetics, and other amines as antiviral agents. Proc Natl Acad Sci U S A. 1981;78(6):3605-9.

53. Shimizu Y, Yamamoto S, Homma M, Ishida N. Effect of chloroquine on the growth of animal viruses. Archiv f Virusforschung. 1972;36(1):93-104

54. Keyaerts E, Vijgen L, Maes P, Neyts J, Van Ranst M. In vitro inhibition of severe acute respiratory syndrome coronavirus by chloroquine. Biochem Biophys Res Commun. 2004;323(1):264-8.

55. Shen L, Yang Y, Ye F, Liu G, Desforges M, Talbot PJ, et al. Safe and sensitive antiviral screening platform based on recombinant human coronavirus OC43 expressing the luciferase reporter gene. Antimicrob Agents Chemother. 2016;60(9):5492-503.

56. de Wilde AH, Jochmans D, Posthuma CC, Zevenhoven-Dobbe JC, van Nieuwkoop S, Bestebroer TM, et al. Screening of an FDA-approved compound library identifies four small-molecule inhibitors of Middle East respiratory syndrome coronavirus replication in cell culture. Antimicrob Agents Chemother. 2014;58(8):4875-84.

57. Wang M, Cao R, Zhang L, Yang X, Liu J, Xu M, et al. Remdesivir and chloroquine effectively inhibit the recently emerged novel coronavirus (2019-nCoV) in vitro. Cell Res. 2020;30(3):269-71.

58. Yao X, Ye F, Zhang M, Cui C, Huang B, Niu P, et al. In vitro antiviral activity and projection of optimized dosing Design of Hydroxychloroquine for the treatment of severe acute respiratory syndrome coronavirus 2 (SARS-CoV-2). Clin Infect Dis. 2020.

59. Andreania J, Le Bideaua M, Duflota I, Jardota P, Rollanda C, Boxbergera M, et al. In vitro testing of hydroxychloroquine and azithromycin on SARS-CoV2 shows 1 synergistic effect 2. Lung. 2020;21:22.

60. Keyaerts E, Li S, Vijgen L, Rysman E, Verbeeck J, Van Ranst M, et al. Antiviral activity of chloroquine against human coronavirus OC43 infection in newborn mice. Antimicrob Agents Chemother. 2009;53(8):3416-21.

61. Paton NI, Lee $L, X u Y$, Ooi EE, Cheung YB, Archuleta $S$, et al. Chloroquine for influenza prevention: a randomised, double-blind, placebo controlled trial. Lancet Infect Dis. 2011;11(9):677-83.

62. Delogu I, de Lamballerie X. Chikungunya disease and chloroquine treatment. J Med Virol. 2011;83(6):1058-9.

63. Gao J, Tian Z, Yang X. Breakthrough: chloroquine phosphate has shown apparent efficacy in treatment of COVID-19 associated pneumonia in clinical studies. Biosci Trends. 2020;14(1):72-3.

64. Efficacy of hydroxychloroquine in patients with COVID-19: results of a randomized clinical trial. medRxiv. Available from: https://www.medrxiv.org/ content/10.1101/2020.03.22.20040758v3

65. Molina JM, Delaugerre C, Goff JL, Mela-Lima B, Ponscarme D, Goldwirt L, et al. No evidence of rapid antiviral clearance or clinical benefit with the combination of hydroxychloroquine and azithromycin in patients with severe COVID-19 infection. Med Mal Infect. 2020.

66. Barbosa J, Kaitis D, Freedman R, Le K, Lin X. Clinical outcomes of hydroxychloroquine in hospitalized patients with COVID-19- a quasirandomized comparative study. Bibliovid. [cited 2020 Apr 15]. Available from: https://bibliovid.org/clinical-outcomes-of-hydroxychloroquine-inhospitalized-patients-with-covid-19-a-302.

67. Fox LM, Saravolatz LD. Nitazoxanide: a new Thiazolide Antiparasitic agent. Clin Infect Dis. 2005;40(8):1173-80.

68. Rossignol J-F. Nitazoxanide: a first-in-class broad-spectrum antiviral agent. Antivir Res. 2014;110:94-103.

69. Rossignol J-F. Nitazoxanide, a new drug candidate for the treatment of Middle East respiratory syndrome coronavirus. J Infect Public Health. 2016;9(3):227-30.

70. Hong SK, Kim HJ, Song CS, Choi IS, Lee JB, Park SY. Nitazoxanide suppresses IL-6 production in LPS-stimulated mouse macrophages and TG-injected mice. Int Immunopharmacol. 2012;13(1):23-7.

71. Cao J, Forrest JC, Zhang X. A screen of the NIH clinical collection small molecule library identifies potential anti-coronavirus drugs. Antivir Res. 2015; 114:1-10. 
72. Gamiño-Arroyo AE, Guerrero ML, McCarthy S, Ramírez-Venegas A, LlamosasGallardo B, Galindo-Fraga A, et al. Efficacy and safety of Nitazoxanide in addition to standard of Care for the Treatment of severe acute respiratory illness. Clin Infect Dis. 2019;69(11):1903-11.

73. Chen W, Mook RA, Premont RT, Wang J. Niclosamide: beyond an antihelminthic drug. Cell Signal. 2018;41:89-96.

74. Frayha GJ, Smyth JD, Gobert JG, Savel J. The mechanisms of action of antiprotozoal and anthelmintic drugs in man. Gen Pharmacol Vasc S. 1997; 28(2):273-99.

75. Xu J, Shi PY, Li H, Zhou J. Broad spectrum antiviral agent niclosamide and its therapeutic potential. ACS Infect Dis. 2020;6(5):909-15.

76. Jung E, Nam S, Oh H, Jun S, Ro H-J, Kim B, et al. Neutralization of acidic intracellular vesicles by Niclosamide inhibits multiple steps of the dengue virus life cycle in vitro. Sci Rep. 2019;9(1):8682.

77. Jurgeit A, McDowell R, Moese S, Meldrum E, Schwendener R, Greber UF. Niclosamide is a proton carrier and targets acidic endosomes with broad antiviral effects. PLoS Pathog. 2012;8(10):e1002976.

78. Kao J-C, HuangFu W-C, Tsai T-T, Ho M-R, Jhan M-K, Shen T-J, et al. The antiparasitic drug niclosamide inhibits dengue virus infection by interfering with endosomal acidification independent of mTOR. Beasley DWC, editor. PLoS Negl Trop Dis. 2018;12(8):e0006715.

79. Gassen NC, Niemeyer D, Muth D, Corman VM, Martinelli S, Gassen A, et al. SKP2 attenuates autophagy through Beclin1-ubiquitination and its inhibition reduces MERS-Coronavirus infection. Nat Commun. 2019;10(1):5770.

80. Kao JC, HuangFu WC, Tsai TT, Ho MR, Jhan MK, Shen TJ, et al. The antiparasitic drug niclosamide inhibits dengue virus infection by interfering with endosomal acidification independent of mTOR. PLoS Negl Trop Dis. 2018;12(8):e0006715.

81. Laing R, Gillan V, Devaney E. Ivermectin - old drug, new tricks? Trends Parasitol. 2017;33(6):463-72.

82. Caly L, Druce JD, Catton MG, Jans DA, Wagstaff KM. The FDA-approved drug ivermectin inhibits the replication of SARS-CoV-2 in vitro. Antivir Res. 2020;178:104787.

83. Yamasmith E, Avirutnan P, Mairiang D, Tanrumluk S, Suputtamongkol Y, Saleh-arong FA, et al. Efficacy and Safety of Ivermectin against Dengue Infection: A Phase III, Randomized, Double-blind, Placebo-controlled Trial. ClinicalTrials.gov Identifier: NCT02045069. 2015.

84. Chu C, Cheng V, Hung I, Wong M, Chan K, Chan K, et al. Role of lopinavir/ ritonavir in the treatment of SARS: initial virological and clinical findings. Thorax. 2004;59(3):252-6.

85. Sheahan TP, Sims AC, Leist SR, Schäfer A, Won J, Brown AJ, et al. Comparative therapeutic efficacy of remdesivir and combination lopinavir, ritonavir, and interferon beta against MERS-CoV. Nat Commun. 2020;11(1):222.

86. Chan JF-W, Yao Y, Yeung M-L, Deng W, Bao L, Jia L, et al. Treatment with Lopinavir/ritonavir or interferon- $\beta 1 \mathrm{~b}$ improves outcome of MERS-CoV infection in a nonhuman primate model of common marmoset. J Infect Dis, 2015;212(12):1904-13.

87. Park SY, Lee JS, Kim J, Joo E-J, Eom JS, Peck KR. 2491. Post-exposure prophylaxis with ribavirin plus Lopinavir/ritonavir for Middle East respiratory syndrome in healthcare workers. Open Forum Infect Dis. 2018;5(Suppl 1):S747-8.

88. Que TL, Wong VC, Yuen KY. Treatment of severe acute respiratory syndrome with lopinavir/ritonavir: a multicentre retrospective matched cohort study. Hong Kong Med J. 2003;9(6):399-406.

89. Izquierdo L, Helle F, François C, Castelain S, Duverlie G, Brochot E. Simeprevir for the treatment of hepatitis $C$ virus infection. Pharmgenomics Pers Med. 2014;7:241-9.

90. Alamri MA, Tahir ul Qamar M, Alqahtani SM. Pharmacoinformatics and molecular dynamic simulation studies reveal potential inhibitors of SARSCoV-2 Main protease 3CLpro. Preprints. 2020:2020020308.

91. Hosseini FS, Amanlou M. Simeprevir, potential candidate to repurpose for coronavirus infection: virtual screening and molecular docking study. Preprints. 2020:2020020438.

92. Sheahan TP, Sims AC, Graham RL, Menachery VD, Gralinski LE, Case JB, Leist SR, Pyrc K, Feng JY, Trantcheva I, Bannister R. Broad-spectrum antiviral GS5734 inhibits both epidemic and zoonotic coronaviruses. Sci Transl Med. 2017;9(396)

93. Siegel D, Hui HC, Doerffler E, Clarke MO, Chun K, Zhang L, et al. Discovery and synthesis of a Phosphoramidate prodrug of a Pyrrolo[2,1-f][triazin-4amino] adenine C-nucleoside (GS-5734) for the treatment of Ebola and emerging viruses. J Med Chem. 2017;60(5):1648-61.
94. Dyer O. Two Ebola treatments halve deaths in trial in DRC outbreak. BMJ. 2019;366.

95. Mulangu S, Dodd LE, Davey RT, Tshiani Mbaya O, Proschan M, Mukadi D, et al. A randomized, controlled trial of Ebola virus disease therapeutics. N Engl J Med. 2019;381(24):2293-303.

96. Warren TK, Jordan R, Lo MK, Ray AS, Mackman RL, Soloveva V, et al. Therapeutic efficacy of the small molecule GS-5734 against Ebola virus in rhesus monkeys. Nature. 2016;531(7594):381-5.

97. Gordon CJ, Tchesnokov EP, Feng JY, Porter DP, Gotte M. The antiviral compound remdesivir potently inhibits RNA-dependent RNA polymerase from Middle East respiratory syndrome coronavirus. J Biol Chem. 2020; 295(15):4773-9.

98. Holshue ML, DeBolt C, Lindquist S, Lofy KH, Wiesman J, Bruce H, et al. First Case of 2019 novel coronavirus in the United States. N Engl J Med. 2020; 382(10):929-36.

99. Kujawski SA, Wong KK, Collins JP, Epstein L, Killerby ME, Midgley CM, et al. First 12 patients with coronavirus disease 2019 (COVID-19) in the United States. Public Global Health. 2020;medrxiv 2020.03.09.20032896.

100. Goldhill DH, te Velthuis AJW, Fletcher RA, Langat P, Zambon M, Lackenby A, et al. The mechanism of resistance to favipiravir in influenza. Proc Natl Acad Sci U S A. 2018;115(45):11613-8.

101. Chen C, Huang J, Cheng Z, Wu J, Chen S, Zhang Y, et al. Favipiravir versus Arbidol for COVID-19: a randomized clinical trial. medRxiv. 2020;2020.03.17. 20037432.

102. Cai Q, Yang M, Liu D, Chen J, Shu D, Xia J, et al. Experimental treatment with Favipiravir for COVID-19: an open-label control study. Engineering. 2020;\$2095809920300631.

103. Elfiky AA. Anti-HCV, nucleotide inhibitors, repurposing against COVID-19. Life Sci. 2020;248:117477.

104. Taylor R, Kotian P, Warren T, Panchal R, Bavari S, Julander J, et al. BCX4430 a broad-spectrum antiviral adenosine nucleoside analog under development for the treatment of Ebola virus disease. J Infect Public Health. 2016;9(3):220-6

105. Yamamoto M, Matsuyama S, Li X, Takeda M, Kawaguchi Y, Inoue J, et al. Identification of Nafamostat as a potent inhibitor of Middle East respiratory syndrome coronavirus S protein-mediated membrane fusion using the Split-protein-based cell-cell fusion assay. Antimicrob Agents Chemother. 2016;60(11):6532-9.

106. Berkhout B, Eggink D, Sanders RW. Is there a future for antiviral fusion inhibitors? Curr Opin Virol. 2012;2(1):50-9.

107. Anand K, Ziebuhr J, Wadhwani P, Mesters JR, Hilgenfeld R. Coronavirus Main proteinase (3CLpro) structure: basis for Design of Anti-SARS. Drugs. 2003;300:6.

108. Scott LJ. Tocilizumab: a review in rheumatoid arthritis. Drugs. 2017;77(17): 1865-79.

109. Mehta P, McAuley DF, Brown M, Sanchez E, Tattersall RS, Manson JJ. COVID19: consider cytokine storm syndromes and immunosuppression. Lancet. 2020;395(10229):1033-4.

110. Ruan Q, Yang K, Wang W, Jiang L, Song J. Clinical predictors of mortality due to COVID-19 based on an analysis of data of 150 patients from Wuhan, China. Intensive Care Med. 2020;46(5):846-8.

111. Teijaro JR. The role of cytokine responses during influenza virus pathogenesis and potential therapeutic options. Curr Top Microbiol Immunol. 2015;386:3-22

112. Xu X, Han M, Li T, Sun W, Wang D, Fu B, Zhou Y, Zheng X, Yang Y, Li X, Zhang X. Effective treatment of severe COVID-19 patients with tocilizumab. Proc Natl Acad Sci. 2020.

113. Gritti G, Raimondi F, Ripamonti D, Riva I, Landi F, Alborghetti L, et al. Use of siltuximab in patients with COVID-19 pneumonia requiring ventilatory support. medRxiv. 2020;2020.04.01.20048561.

114. Bian H, Zheng Z-H, Wei D, Zhang Z, Kang W-Z, Hao C-Q, et al. Meplazumab treats COVID-19 pneumonia: an open-labelled, concurrent controlled addon clinical trial. medRxiv. 2020;2020.03.21.20040691.

\section{Publisher's Note}

Springer Nature remains neutral with regard to jurisdictional claims in published maps and institutional affiliations. 